\title{
災害・事故時の環境測定に関連する技術紹介
}

\author{
香川 明文, 井ノ上 哲志, 大塚 岳 \\ 株式会社＼cjkstart堀場製作所（†520-0102 滋賀県大津市苗鹿1-15-1） \\ [2019年 1 月 8 日受付，2019年 1 月 8 日受理 $]$
}

\section{Introduction of the Key Measurement Technology for Disasters and Accidents}

\author{
Akifumi KAGAWA, Satoshi INOUE and Gaku OTSUKA \\ HORIBA, Ltd \\ (1-15-1 Noka, Otsu, Shiga 520-0102) \\ [Received January 8, 2019; Accepted January 8, 2019]
}

Key words: screening on site, portable analyzer, time of flight mass spectrometry

\section{1.はじめに}

災害・事故発生時には, 健康リスク要因の高い物質が周辺に拡散 する可能性があり，それらの物質をオンサイトで迅速に把握するこ とが望まれる。得られた情報は，災害発生場所の近隣住民に対して 注意喚起，避難勧告などのために，適切かつタイムリーに活用され ることが求められる。ここでは定常時及び非定常時での大気測定に 関連すると考えられるシーズ技術について紹介する。

\section{2. 背景}

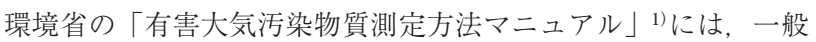
的な環境大気中の揮発性有機化合物（以下 VOCs）濃度を把握する 目的において，既に実績ある測定方法の中から検証試験によりその 基本性能が確認できた化学分析法による標準的方法として, 容器採 取あるいは固体吸着による GC-MS 法（後述）が提示されている。

特に低濃度 VOCs 分析においては，前処理や分離分析を含む測 定方法の技術進歩により GC-MS 法だけでなくGC-MS/MS 法, GC $\times \mathrm{GC} / \mathrm{MS}$ 法なども活用され, 高感度検出器の採用も相まって高精 度な優れた手法が採用されている。その反面これらの分析手法を用 いるには専門知識が必要である。装置は大がかりになる傾向があ り，大きなスペースが必要な設置型装置として分類され，一般的に 容易に持ち運べるような可搬型とは言えない。一方，標準的な分析 法以外には，スクリーニング用途として携帯型や可搬型に用いられ る様々な測定方法があるが, 設置型の標準分析手法に比べるとその 測定精度が劣る傾向にあることは否めない。

健康リスク要因の高い物質がますます多様化している中, 特に災 害・事故発生時における非定常時には，懸念される測定対象物質の 濃度を迅速に把握することが求められる。しかし前述の GC-MS 法 などを利用した化学分析法では，特に現場で夕イムリーに対応する ことは容易でない。このことから災害・事故発生初期には主にスク
リーニング目的として, 専門的な知識がなくても手軽に計測可能で 高感度な多成分ガス分析計が求められる。これらのニーズに対応し た，主に有害大気污染物質中の VOCs を測定するための可搬型装 置に応用可能な技術及び現場で簡単に直接測定できる可搬型装置や 簡易型測定法の一例を紹介する。

\section{3. 分析方法と装置構成}

\section{1 GC-MS 法}

GC-MS 法 (Gas Chromatography-Mass Spectrometry) は, 気化 しやすい成分の同定・定量に用いられる分析手法であり，カラムで 分離させた成分を質量分析計 (MS) でイオン化して分析する方法 である。

試料ガスとキャリアガス（不活性ガス）は，充填剤からなるパッ クドカラムや内壁がコーティングされたキャピラリーカラムに一定 流量で送られ, 固定相に対する気体の吸着性あるいは溶解性の差異 等から試料ガス中の成分が分離される。分離された成分は, カラム 出口に接続された質量分析計 (MS) を通過する過程でガスクロマ トグラムと呼ばれるピークとして出力される。その情報から成分の 定性及び定量を行う分析法である。

装置は, (1)成分分離を行うカラムユニット, (2) MS 分析部, (3)力 ラムユニットや分析器などの温度制御部, (4)キャリアガスやサンプ ル流量を調整する流量制御部などに分けられ, 一般的に周辺機器と して(5) PC を含むデータ処理部, (6)前処理や試料導入部が必要であ る。

【特長】

（1）豊富なライブラリにより，多成分を同時に計測することが可能 である。

（2）揮発性の高い成分，ガス状または気化する成分分析に有効であ る。

（3）一般的に微量な有機成分の定性・定量が可能である。 


\section{2 TOFMS 法}

飛行時間型質量分析法 (Time of Flight Mass Spectrometry) は, 対象とする試料をイオン化した後, 一定エネルギーを与え加速・飛 行させた際にそれぞれのイオンの質量の違いから生ずる飛行速度の 違いを利用して成分種を特定する分析方法である。一定エネルギー で加速されたイオンの飛行速度は質量の平方根に反比例するため, イオン源から検出器に到達する時間はイオンの質量の平方根に比例 し，この飛行時間を検出することによって質量スペクトルを得るこ とができ，成分の特定が可能である2)。

$$
\begin{aligned}
& \frac{1}{2} \mathrm{mv}^{2}=\mathrm{E}, \quad \mathrm{v}=\sqrt{\frac{2 \mathrm{E}}{\mathrm{m}}} \quad \ldots \ldots \ldots \text { (1) } \\
& \mathrm{t}=\frac{1}{\mathrm{v}}=1 \sqrt{\frac{\mathrm{m}}{2 \mathrm{E}}} \quad, \quad \mathrm{t} \propto \sqrt{\mathrm{m}} \cdots \cdots \cdots(2)
\end{aligned}
$$

装置は(1)前処理が不要な試料導入部, (2)試料をイオン化し質量ご とに分離・検出する質量分析部, (3)検出されたイオンを高速処理す る信号処理部, (4)高電圧を供給する電源部の 4 ユニットで構成され ている。

【特長】

（1）多変量解析による濃度演算ソフトを使用し, 解析用ライブラリ を充実させることで，任意成分の定量が可能となり，ガス分離 機能としての前処理が不要である。

(2) TOFMS は生成したイオンを検出するため, 多成分の同時測定 が可能である。

（3） 1 走査が数十 $\mu$ 秒と高速であるため, 走査数を増やすことによ り低濃度域まで検出することも可能である。

\section{3 FTIR 法}

フーリエ変換赤外分光法 (Fourier Transform Infrared Spectroscopy）は, 測定対象試料に赤外線を照射し, 得られる物質 固有の赤外線吸収（以下 IR） スペクトルを利用して成分を定性・ 定量する分析方法である。

装置は主に(1)赤外光源部，(2)検出器，(3)移動鏡を有す二光束の光 学干渉計部, (4)コンピュータを用いて波長（波数）成分に分離（フー リ工変換）してスペクトルを得るデータ処理部，(5)試料室からなる。 検出器は, 一般的に焦電タイプや高感度測定が必要な場合には, 液体窒素で泠却して使用する光伝導型半導体タイプが用いられる。 連続測定用途などでは, ペルチェ素子を冷却手段にした検出器も使 用される ${ }^{3)}$ 。

\section{【特長】}

（1）試料導入後，干渉計内の移動鏡を走査することでIR スペクト ルが得られることから, 前処理なしで迅速な測定が可能である。

（2）IR スペクトルは物質に固有であるため，データベース化され た豊富な標準試料のIRスペクトルと，測定したスペクトルを 照合することで未知試料を同定することが可能である。

（3）多成分の同時測定が可能である。

\section{4 簡易測定法}

VOCs 老測定対象とした時, 簡易的に測定する方法は, 大きく分 けて以下の 3 種類に分類される4)。

(1)光イオン化検出器 (PID) を用いる方法

(2)半導体などのセンサーを用いる方法

(3)検知管を用いる方法

市販されているVOCs 簡易測定器の多くは, 成分を同定すると いうよりVOCs を包括的に測定することが可能である。VOCs 以外 のガス成分に感度を示したり，VOCs の成分によって感度差が見ら れる場合もあるが, 相対的な感度を把握することができる。検出器 に半導体ガスセンサーを用いてガスクロマトグラフィーと組み合わ せることで, 個別の VOCs を高感度に測定できる装置もあり, 試 料を濃縮するなどの前処理を行うことなく，オンサイト測定を目的 としても使用可能である5)。

【特長】

一般的に小型, 軽量, 携带型装置が多く, 操作が容易で, 保守性 に優れている。

\section{4. おわりに}

想定される災害・事故発生時の環境測定用として, 汎用性が高い 装置が求められるのは言うまでもなく, 可搬型でかつ想定される対 象成分を可能な限り多く同時に低濃度から高濃度まで 1 台で測定で きる装置が望ましい。現場で電源が得られない場合も想定し, 装置 をバッテリーで駆動できれば，より迅速な対応が可能となる。

今回紹介したTOF-MS 法を利用した装置だけでなく，GC-MSの 他 FITR どの分析手法を採用した装置も，今日の技術進歩により コンパクトになり，スクリーニング用可搬型として多成分を測定で きるようになってきている。環境測定用として定常時, 非定常時と もに役立つ可搬型測定装置が, 計測という断面で災害対応力の強化 に繋がるだけでなく安全, 安心な環境を維持することに貢献できる ものと期待している。

\section{文 献}

1) 環境省: 有害大気污染物質測定方法マニュアル（平成23年 3 月 改訂） https://www.env.go.jp/air/osen/manual2/pdf-rev1103/ 01_chpt1-1.pdf（2018年11月28日閲覧）

2) 平野恭司, 米田有利 : ポータブル質量分析計 MS-200, HORIBA Technical Reports Readout, 18，57-60（1999）

3）西村克美：高性能汎用 FT-IR FT-700シリーズ, HORIBA Technical Reports Readout, 13，69-74 (1996)

4）環境省：VOC簡易測定技術について（資料2-1） https:// www.env.go.jp/policy/etv/pdf/comm/h20/k01/mat02-1.pdf (2018年12月12日閲覧)

5）環境省：環境技術実証事業 VOC 等簡易測定技術分野 平成26 年度実証対象技術の環境保全効果等，8 